4 Chatterjee A, Mahalanabis D, Jalan K N. Oral rehydration in infantile diarrhoea. Arch Dis Child 1978; 53: 284-9.

5 Sack D A, Sack R B. Test for enterotoxigenic Escherichia coli using $\mathrm{Y}_{1}$ adrenal cells in miniculture. Infect Immun $1975 ; 11$ : 334-6.

6 Morris G K, Merson M H, Sack D A. Laboratory investigation of diarrhea in travelers to Mexico: evaluation of methods for detecting enterotoxigenic Escherichia coli. J Clin Microbiol 1976; 3: 486-95.

7 Yolken R H, Kim H W, Clem T. Enzyme-linked immunosorbent assay (ELISA) for detection of human reovirus- like agent of infantile gastroenteritis. Lancet 1977; ii: 263-6.

8 Mahalanabis D. Nitrogen balance during recovery from secretory diarrhea of cholera in children. Am J Clin Nutr $1981 ; 34$ : 1548-51.

Correspondence to Dr D Mahalanabis, Kothari Centre of Gastroenterology, 7/2 Diamond Harbour Road, Calcutta 700027 , India.

Received 26 February 1982

\title{
Amniocentesis and fetal lung development
}

\author{
H VYAS, A D MILNER, AND I E HOPKIN \\ Department of Neonatal Medicine and Surgery, City Hospital, Nottingham
}

SUMMARY The crying vital capacity was measured in 10 healthy, term babies after amniocentesis during pregnancy, and in 10 control babies after normal pregnancies. The mean ratio of crying vital capacity to body weight was significantly lower after amniocentesis. This may be caused by the alteration in the lung fluid volume and the diminished intrauterine respiratory movements.

Oligohydramnios secondary to lack of urine production is thought to be responsible for lung hypoplasia in Potter's syndrome. Perlman et al. ${ }^{1}$ however, have reported similar effects on lung growth resulting from chronic leakage of amniotic fluid, not related to renal agenesis. The use of amniocentesis performed for antenatal diagnosis of genetic or neural tube defects has become common. This is generally carried out in the midtrimester. The volume of amniotic fluid at 16 weeks is estimated to be between 130 and $170 \mathrm{ml}$. No ill effects on the fetus have been observed with removal of between 20 and $45 \mathrm{ml}$ of amniotic fluid at 16 weeks, but the procedure produces a pronounced alteration in the fetal movements and a significant decline in the fetal breathing at 24 and 48 hours after amniocentesis. ${ }^{2}$ Studies on animals have shown that amniocentesis performed in the early fetal period can cause lung hypoplasia. ${ }^{3}$ The British study in $1978^{4}$ showed a $1 \%$ increase in severe, unexplained, respiratory distress at birth after amniocentesis, being particularly pronounced between 34 and 37 weeks' gestation. The corresponding American study also revealed this, although the figures were not statistically significant. We therefore decided to study healthy, term neonates delivered to mothers subjected to amniocentesis to assess its effect on lung growth.

\section{Method}

A face mask attached to a pneumotachograph was used for measuring the crying vital capacity. The rim of the rubber mask was coated with soft paraffin to prevent leaks. It was placed over the baby's face enclosing the nose and the mouth. The baby was then stimulated to cry, into the face mask, by flicking the soles of its feet.

The flow signals were transmitted to a differential transducer and recorded on to a 4-channel FM recorder. A total of four to five bursts of crying was recorded. Volume was obtained by electronic integration of flow signals. At the end of the investigation volume was calibrated by injecting a known volume of air across the pneumotachograph, using a syringe. The output of the tape recorder was fed to an oscillograph and the record was obtained on ultraviolet-sensitive paper. The whole record was examined for the maximal deflection in a single cry and this was designated the crying vital capacity. Chest circumference was measured at the level of the nipple at the end of quiet expiration.

\section{Subjects}

We studied 10 healthy, term babies whose mothers had been subjected to amniocentesis. Six mothers had had amniocentesis carried out because of raised maternal serum alpha-fetoprotein levels noted on routine screening. The remaining 4 had been offered amniocentesis because of their age, 35 years or older. 
Table Clinical details and results

\begin{tabular}{|c|c|c|c|c|c|c|}
\hline Group & $\begin{array}{l}\text { Gestation } \\
\text { (weeks) }\end{array}$ & $\begin{array}{l}\text { Birthweight } \\
(k g)\end{array}$ & $\begin{array}{l}\text { Chest circumference } \\
(\mathrm{cm})\end{array}$ & $\begin{array}{l}\text { Age at test } \\
\text { (hours) }\end{array}$ & $\begin{array}{l}\text { Crying vital capacity/ } \\
\text { birthweight }(\mathrm{ml} / \mathrm{kg})\end{array}$ & $\begin{array}{l}C V C / C C \\
(\mathrm{ml} / \mathrm{cm})\end{array}$ \\
\hline \multicolumn{7}{|c|}{ Vaginal $(n=10)$} \\
\hline $\begin{array}{l}\text { Mean } \\
\text { Median }\end{array}$ & $\begin{array}{l}39 \cdot 3 \\
40 \cdot 0\end{array}$ & $\begin{array}{l}3 \cdot 11 \\
3 \cdot 10\end{array}$ & $\begin{array}{l}31 \cdot 8 \\
32 \cdot 1\end{array}$ & $\begin{array}{l}54 \cdot 6 \\
54 \cdot 8\end{array}$ & $\begin{array}{l}31 \cdot 3 * * \\
31 \cdot 4\end{array}$ & $\begin{array}{l}3 \cdot 03 \\
3 \cdot 02\end{array}$ \\
\hline \multicolumn{7}{|c|}{ Amniocentesis $(n=10)$} \\
\hline $\begin{array}{l}\text { Mean } \\
\text { Median }\end{array}$ & $\begin{array}{l}39 \cdot 5 \\
40 \cdot 0\end{array}$ & $\begin{array}{l}3 \cdot 49 \\
3 \cdot 41\end{array}$ & $\begin{array}{l}31 \cdot 4 \\
31 \cdot 0\end{array}$ & $\begin{array}{l}65 \cdot 7 \\
55 \cdot 0\end{array}$ & $\begin{array}{l}27 \cdot 3^{* *} \\
27 \cdot 0\end{array}$ & $\begin{array}{l}3 \cdot 01 \\
3 \cdot 07\end{array}$ \\
\hline
\end{tabular}

$\mathrm{CVC}=$ crying vital capacity, $\mathrm{CC}=$ chest circumference.

$* * \mathbf{P}<0.05$.

Amniocentesis was performed at between 15 and 24 weeks. All the babies had been delivered vaginally and none had required resuscitation at birth. None had any evidence of respiratory problems after delivery. For our control group we studied 10 babies also delivered vaginally who had been well since delivery. All babies were studied between 2 and 5 days of age by which time lung fluid absorption had occurred and thoracic gas volume stabilised. A verbal consent was obtained from the parents before the investigations.

\section{Results}

The clinical details of the two groups are shown in the Table. The mean gestational age, birthweight, and chest circumference were not significantly different.

The crying vital capacity calculated in terms of body weight $(\mathrm{kg})$ was $27.3 \pm 3.96$ in the index group compared with $31.3 \pm 4.52 \mathrm{ml} / \mathrm{kg}$ in the controls. These results were significantly different $(P<0.05)$. The crying vital capacity : chest circumference ratio was virtually identical in the two groups.

\section{Discussion}

Crying vital capacity has been shown to be both rapid and reproducible as a measure of lung volume, similar to the vital capacity in the older child. Chiswick and Milner ${ }^{5}$ noted lower crying vital capacities in babies with hyaline membrane disease and transient tachypnoea of the newborn. In both conditions there is a loss in functional residual capacity. We thus felt justified to use crying vital capacity as an index of lung volume as it is likely to provide a more sensitive index of lung growth than thoracic gas volume.

Our preliminary findings suggest that there is a diminished crying vital capacity in infants born to mothers subjected to amniocentesis. The implication of this finding is that the lung volume may be reduced as a result of amniocentesis. Studies on experimental animals have shown that both lung liquid secretion ${ }^{6}$ and intrauterine breathing ${ }^{7}$ are responsible for lung growth. Amniocentesis may alter both these factors and thus reduce lung size. Drainage of lung fluid may ensue on reduction of amniotic fluid volume causing peripheral lung units to collapse leading to failure of normal growth. In Alcorn's fetal lambs ${ }^{6}$ drainage of lung liquid resulted in reduction of lung tissue growth. Wigglesworth and Desai ${ }^{8}$ have suggested that intrauterine breathing may influence development of the acinus by controlling the volume of liquid retained within the lungs. Amniocentesis reduces fetal breathing for up to 48 hours. Both these factors may influence lung development at a time when proliferation of lung cell is at its maximum, resulting in diminished growth.

These are preliminary results and further work is needed to confirm the findings.

\section{References}

1 Perlman M, Williams J, Hirsch M. Neonatal pulmonary hypoplasia after prolonged leakage of amniotic fluid. Arch Dis Child 1976; 51 : 349-53.

2 Manning F A, Platt L D, LeMay M. Effect of amniocentesis on fetal breathing movements. $\mathrm{Br}$ Med $J 1977$; ii: $1582-3$.

3 Blackburn W R, Logsdon P A, Delli-Bovi J. Fetal lung development after amniocentesis (abstract). Pediatr Res $1978 ; 12$ : 515.

4 Medical Research Council. An assessment of the hazards of amniocentesis. Br J Obstet Gynaecol 1978; 85: Supplement 2, 1-41.

5 Chiswick M L, Milner R D G. Crying vital capacity. Measurement of neonatal lung function. Arch Dis Child $1976 ; 51: 22-7$.

- Alcorn D, Adamson T M, Lambert T F, Maloney J E, Ritchie B C, Robinson P M. Morphological effects of chronic tracheal ligation and drainage in the fetal lamb lung. J Anat 1977; 123: 649-60.

7 Wigglesworth J S, Winston R M L, Bartlett K. Influence of the central nervous system on fetal lung development. Arch Dis Child 1977; 52: 965-7.

8 Wigglesworth J S, Desai R. Effect on lung growth of cervical cord section in the rabbit fetus. Early Hum Dev 1979; 3: 51-65.

Correspondence to Dr $\mathbf{H}$ Vyas, Department of Neonatal Medicine and Surgery, City Hospital, Hucknall Road, Nottingham NG5 1PD.

Received 5 April 1982 